This is an author produced version of a paper published in Journal of Trace Elements in Medicine and Biology. This paper has been peer-reviewed but does not include the final publisher proof-corrections or journal pagination.

Citation for the published paper:

Gerhardsson, Lars and Akantis, Anna and Lundstrom, Nils-Goran and Nordberg, Gunnar F and Schütz, Andrejs and Skerfving, Staffan.

"Lead concentrations in cortical and trabecular bones in deceased smelter workers."

J Trace Elem Med Bio, 2005, Vol: 19, Issue: 2-3, pp. 209-15. http://dx.doi.org/10.1016/j.jtemb.2005.06.004

Access to the published version may require journal subscription. Published with permission from: Elsevier 
Style: J Trace Elem Med Biol

\section{LEAD CONCENTRATIONS IN CORTICAL AND TRABECULAR BONES IN DECEASED SMELTER WORKERS}

By

L Gerhardsson1,2,3 , A Akantis², N-G Lundström¹, GF Nordberg1, A Schütz ${ }^{2}$, S Skerfving 2

1. Environmental Medicine, Dept of Public Health and Clinical Medicine, University of Umeå, SE-901 87 Umeå, Sweden

2. Department of Occupational and Environmental Medicine, University Hospital, SE-221 85 Lund, Sweden

3. Department of Occupational and Environmental Medicine, Sahlgrenska University Hospital, SE-412 66 Göteborg, Sweden

Reprint requests to: Lars Gerhardsson, dept of Occupational and Environmental Medicine, Sahlgrenska University Hospital, SE-412 66 Göteborg, Sweden.

Tel: $+46+31+3438103$; FAX: +46-31-40 9728

E-mail: lars.gerhardsson@ymk.gu.se

\section{ABSTRACT}


The aim of the study was to compare bone lead concentrations in cortical and trabecular bones in long-term exposed primary copper and lead smelter workers, and to relate the measured concentrations to the previous lead exposure of the workers.

Lead concentrations in seven bones (trabecular: sternum, vertebrae, iliac crest, rib; cortical: femur, left forefinger, and temporal bone) were determined by electrothermal atomic absorption spectrometry in 32 male, long-term exposed copper and lead smelter workers, and compared with levels in ten male occupationally unexposed referents. A time-integrated blood lead index (CBLI) was calculated for each worker.

The lead levels in the seven studied bones were all significantly higher in active and retired lead workers as compared with the reference group $(\mathrm{p} \leq 0.003)$. The highest lead concentrations among the workers were observed in finger bone (median $106 \mathrm{ppm}$ ), followed in order by vertebrae, iliac crest and sternum. The highest quotients between median bone lead concentrations of workers vs referents were observed for trabecular bones (sternum 12.3, iliac crest 11.8, rib 8.8 and vertebrae 8.5 ). In retired workers, strong positive correlations were noted between lead levels in sternum and iliac crest $\left(\mathrm{r}_{\mathrm{s}}=0.91 ; \mathrm{p}<0.001\right)$ and femur and temporal bone $\left(\mathrm{r}_{\mathrm{s}}=0.88, \mathrm{p}<0.001\right)$. Neither CBLI nor exposure-time was related to the bone lead concentrations in any of the studied groups.

The findings indicate similarities in the metabolism for bones with the same basic structure. The highest lead concentrations were found in finger bone, which can be used for retrospective exposure evaluations in lead exposed populations, e.g. through XRFmeasurements.

Key-words: Cortical and trabecular bones, smelter workers, lead exposure 


\section{INTRODUCTION}

The skeleton is the main depot of inorganic lead, harboring more than $90 \%$ of the body burden (1). The skeletal content in a long-term exposed lead worker can exceed $1 \mathrm{~g}$ (2). The biological half-time in bone varies considerably in different types of cortical (makes up about $80 \%$ of the skeleton) and trabecular bones ( $20 \%$ of the skeleton). The half-time in trabecular bones is usually shorter than in cortical bones, and may vary from a few years in vertebrae (3) and up to 16 years in calcaneus (4). Half-times in cortical bones are often in the range of 5-15 years (5-10), but may exceed 25 years (4).

In retired lead workers, the endogenous exposure from skeletal lead will influence the blood lead concentrations. The skeletal influx and efflux of lead in active and retired workers are related to the plasma lead concentrations and are influenced by several factors, e.g. nutritional status, calcium metabolism and hormones such as 1,25 dihydrocholecalciferol, oestrogens, parathyroid hormone, calcitonin, growth hormone, prolactin and thyrotropins (11).

Several methods have been discussed for retrospective exposure estimations in lead exposed populations when studying chronic effects. One option is a time-integrated blood lead index, if the subjects have been regularly monitored for a long time period. Often, however, there is lack of consistent long-term data, which hampers this type of calculations. An alternative may be in vivo measurements of lead in bone, which in some studies have shown good correlations to time-integrated blood lead indices $(4,9)$. Such measurements may be of value in epidemiological studies of adverse health effects in lead exposed populations, for whom data on previous blood lead levels are lacking (9). 
The aim of the present study was to compare bone lead concentrations in different types of cortical and trabecular bones in deceased, long-term exposed smelter workers. This skeletal lead pattern may be valuable to elucidate which bone/bones that can be appropriate for exposure estimations by in vivo bone lead determinations. The lead concentrations determined were also related to more commonly used exposure indices such as exposure time, time-integrated blood lead index and period of retirement. 


\section{MATERIALS AND METHODS}

Lead concentrations in bone were determined in 32 male, long-term lead-exposed workers at a primary copper and lead smelter in northern Sweden. Comparison was made with 10 deceased male subjects from the city of Skellefteå, about $17 \mathrm{~km}$ from the smelter, and from two rural areas about $50 \mathrm{~km}$ from the smelter.

Lead samples were collected from the upper part of sternum (manubrium), from femur, about $1 \mathrm{dm}$ above the knee-region, from the middle phalanx of the left forefinger, from the spinal processes of the vertebrae in the L1-L2-region, from the right iliac crest, from the $3 \mathrm{rd}$ rib, about $1 \mathrm{dm}$ to the right of sternum, and from the right temporal bone. All samples were collected with a circular sawing machine and stored in acid-washed polyethene-vessels at $-20^{\circ} \mathrm{C}$, in a freezing-room at the department of Environmental Medicine, University of Umeå.

\section{Analysis}

After transferring the samples to the laboratory at the dept of Occupational and Environmental Medicine, University Hospital, Lund, Sweden, samples with a wet weight of $0.2-0.5 \mathrm{~g}$ were obtained by use of a diamond cutting wheel, and transferred into acid-washed glass tubes. The dry weight was determined after drying at $110{ }^{\circ} \mathrm{C}$ for 16 hours in an oven. Thereafter, a combined wet and dry ashing procedure took place: $0.20 \mathrm{~mL}$ concentrated nitric acid (Merck Suprapur) was added and the glass tubes were heated for 1.5 hours at $120{ }^{\circ} \mathrm{C}$ in a heating block. After cooling, another $0.20 \mathrm{~mL}$ of nitric acid was added and the heating procedure was repeated. Again, after cooling, $0.20 \mathrm{~mL}$ of an acid mixture ( $95 \%$ nitric acid, $5 \%$ perchloric acid) was added and the 
samples were heated gradually up to $430{ }^{\circ} \mathrm{C}$ during two hours. The salt residue was dissolved in $0.20 \mathrm{~mL}$ concentrated nitric acid and $9.8 \mathrm{~mL}$ deionised water. In each series of 24 samples, 4-6 blanks were included.

The lead content was analysed by electrothermal atomic absorption spectrometry (Perkin-Elmer AAS 5000; HGA 500/AS 40/PRS-10), using the method of standard addition. Sample aliquots of $0.50 \mathrm{~mL}$ were mixed with $0.60 \mathrm{~mL} 2 \%$ nitric acid including $0.050 \mu \mathrm{g}$ lead standard in one of the samples. Twenty $\mu \mathrm{L}$ was injected and dried at $100{ }^{\circ} \mathrm{C}(\operatorname{ramp} 15 \mathrm{~s}$; hold $10 \mathrm{~s})$, ashed at $600{ }^{\circ} \mathrm{C}(\operatorname{ramp} 10 \mathrm{~s}$; hold $15 \mathrm{~s})$, and atomized at $2300{ }^{\circ} \mathrm{C}(10 \mathrm{~s}$; miniflow $50 \mathrm{~mL} \mathrm{Ar} / \mathrm{min})$. The absorbance was measured at $283.3 \mathrm{~nm}$. Deuterium background correction was undertaken. Calcium was determined by flame AAS after dilution 100 times with $2 \%$ nitric acid containing $1 \%$ lanthanum. The detection limit for lead was about $0.01 \mu \mathrm{g}$ per sample, corresponding to about 1 $\mu \mathrm{g} / \mathrm{g}$ wet weight and $10 \mu \mathrm{g} / \mathrm{g} \mathrm{Ca}$. The $\mathrm{CV}$ of the lead and calcium determinations (dry weight) was 18 and $16 \%$, respectively. No relevant human bone lead materials with certified reference values were available at the time of the study. Thus, the accuracy of the method was tested by analysing 12 samples taken at autopsy from a subject without known lead exposure. Into six of the samples , $0.5 \mu \mathrm{g}$ of lead was added before ashing. The average recovery was $105 \%$ (SD 6.2; range 98-114) after correction for the lead originally present in the six samples without lead addition (mean 3; SD 0.9; range $2.0-4.4 \mu \mathrm{g} / \mathrm{g}$ dry weight). 


\section{Work history}

Detailed information about employment-period and work-sites at the smelter was gained from the Company.

\section{Blood lead register}

The results from the biological monitoring of lead in blood and from the air lead measurements have been stored in a data-base at the company. Regular measurements of lead in blood at the smelter started in 1950. From the database it has been possible to calculate a time-integrated blood lead index (CBLI; summation of annual mean blood lead values; $\mu \mathrm{mol} / \mathrm{L})$, reflecting the previous lead exposure. This index has been related to measured lead concentrations in cortical and trabecular bones.

In the reference group a mean blood lead value of approximately $0.4 \mu \mathrm{mol} / \mathrm{L}$ can be estimated during the study period. Assuming a follow-up period of 30 years, the same as the mean exposure time among the workers, the corresponding baseline CBLI for the referents would be approximately $12 \mu \mathrm{mol} / \mathrm{L}$ (c.f. Table 1).

\section{STATISTICS}

Parametric statistical methods (Student's t-test) were used for variables such as age, exposure time and period of retirement, which showed a normal distribution (checked by Normal Probability Plots). As the bone lead concentrations showed skewed distributions, nonparametric statistical processing was applied (Mann-Whitney U-test, Spearman's correlation coefficients). P-values $<0.05$ were regarded as statistically significant. Calculations were performed using the Statistical Package for the Social Sciences (SPSS version 12.0). 


\section{RESULTS}

\section{Age, time of exposure, period of retirement}

Mean values and standard deviations for age, time of exposure and period of retirement among lead workers and referents are presented in table 1. The age was about the same in both groups.

\section{Lead in bone}

Median values and ranges for lead concentrations in sternum, femur, finger-bone, vertebrae (spinal process), iliac crest, rib and temporal bone as well as for cumulative blood lead index (CBLI) for lead workers and controls are presented in table 1 . The lead concentrations in the seven studied bones were all significantly higher $(\mathrm{p}<0.001)$ among exposed workers compared to referents. This was the case for both active $(\mathrm{p}<0.001)$ and retired $(\mathrm{p} \leq 0.003)$ workers. No significant differences in bone lead concentrations were, however, noted when comparing active and retired lead workers.

In active lead workers, the highest bone lead concentrations were observed in fingerbone (mainly cortical), followed in order by more trabecular bones such as iliac crest, vertebra, sternum and rib. The pattern was very similar among retired lead workers. The referents, however, showed a somewhat different pattern with the highest bone lead concentrations in three, mainly cortical bones, temporal bone, finger bone and femur.

The largest difference in lead concentrations when comparing all lead workers and referents was noted for trabecular bones (quotients between median values: sternum 12.3, iliac crest 11.8, rib 8.8 and vertebra 8.5$)$. The corresponding quotients for the 
mainly cortical bones were somewhat lower (finger-bone 7.5, femur 4.3 and temporal bone 3.9). The relationships between lead concentrations in a mainly cortical bone such as finger bone versus lead concentrations in mainly trabecular bones (e.g. sternum and vertebrae) are shown in table 2.

\section{Correlation coefficients}

Among retired lead workers, the strongest positive correlations were observed between lead concentrations in sternum and iliac crest $\left(\mathrm{r}_{\mathrm{s}}=0.91, \mathrm{p}<0.001\right)$, femur and temporal bone $\left(\mathrm{r}_{\mathrm{s}}=0.88, \mathrm{p}<0.001\right)$, finger bone and $\mathrm{rib}\left(\mathrm{r}_{\mathrm{s}}=0.85, \mathrm{p}<0.001\right)$, and sternum and rib $\left(r_{s}=0.81, p=0.001\right)$. Among the active lead workers no significant positive correlations were observed between the seven bones. In neither group, age, employment-time, period of retirement (for retired workers) or cumulative blood lead index (CBLI) were significantly associated with any of the bone lead concentrations.

In the reference group strong positive correlations were noted between the mainly cortical bones femur and temporal bone $\left(\mathrm{r}_{\mathrm{s}}=0.96, \mathrm{p}<0.001\right)$, and finger bone and temporal bone $\left(\mathrm{r}_{\mathrm{s}}=0.80, \mathrm{p}=0.017\right)$. Significant positive correlations were also observed between finger bone and sternum $\left(\mathrm{r}_{\mathrm{s}}=0.83, \mathrm{p}=0.010\right)$, and finger bone and iliac crest $\left(\mathrm{r}_{\mathrm{s}}=0.82, \mathrm{p}=0.012\right)$. Age was not related to any of the bone lead concentrations. 


\section{DISCUSSION}

The active and retired lead workers in this study have had a long-term and fairly high lead exposure at a primary smelter, which is visualized by the cumulative blood lead index (c.f. table 1). The lead exposure, however, have gradually declined with time over the years because of reconstruction and modernization, improved ventilation and increased use of personal protective devices (12). When the regular blood lead monitoring program started in 1950, the mean blood lead level among the lead workers at the smelter was about $3 \mu \mathrm{mol} / \mathrm{L}$, compared with about $1.6 \mu \mathrm{mol} / \mathrm{L}$ in 1987 , when the collection of the material ended. The long-term lead exposure has caused a considerable bone lead accumulation in the exposed workers. As evident from table 1, the median values of the lead concentrations in the seven studied bones are about $4-12$ times higher in lead workers as compared with the levels in the reference group.

\section{In this study the quotients between median lead concentrations in finger bone,} which is a mainly a cortical bone, and median lead levels in mainly trabecular bones such as sternum and vertebrae, in general varied between 1.2 and 1.4 (c.f.

Table 2). Several factors will have an impact on the biological half-time of lead in bone. The half-time is often shorter in trabecular than in cortical bone. A biological half-time of a few years in the trabecular bone of the spinal processes of the lumbar vertebrae has been reported by Schütz et al (3). Longer half-times of about 5-15 years have been estimated in mainly cortical finger-bone (5-9). Accordingly, measurements in finger-bone (mainly cortical) in active lead workers, probably reflects somewhat more of the trabecular component of the skeleton, as compared with measurements in retired lead workers Also, the proportion between trabecular and cortical bone differs in different parts of the skeleton. Thus, the measurement depth is of importance for the lead pool. There may also be individual differences in the proportion between cortical 
and trabecular bone within the same part of the skeleton. Furthermore, there are individual age-dependent differences regarding the turn-over rate in different skeletal parts. A recent study by Brito et al (13) reported a shorter half-life for the lead release from tibia for lead workers with an age less than $40 \mathrm{y}$, as compared with older workers. Similar results have been reported in a study of about 800 lead exposed Korean workers (10), indicating that tibia lead concentrations and stores are less bioavailable in older workers. Furthermore, workers with a low intensity of lead exposure $(\mathbf{B}-\mathbf{P b}<\mathbf{1 . 2}$ $\boldsymbol{\mu m o l} / \mathbf{L}$ ) showed a higher tibia lead clearance rate than workers with a more intense exposure $\left(\mathrm{T}_{1 / 2} 6.2\right.$ y vs $\left.14.7 \mathrm{y}\right)$. A recent study indicates a non-linear relationship between tibia lead and blood lead (14). The release of lead in bone, e g from patella, into the circulation is influenced by bone resorption (15). Also other factors like age, race, smoking and education may influence bone lead accumulation (16). Accordingly, considerable differences have been reported in different studies of biological half-times in cortical and trabecular bones.

The bone lead concentrations in cortical and trabecular bones in our study is comparable to earlier reported bone lead concentrations from XRF-measurements in lead-exposed subjects and occupationally unexposed groups in Sweden (4-6, 8-9, 1719). As earlier discussed, the environmental lead exposure from air, food, and water varies considerably in different parts of the world. Thus, bone lead concentrations in active lead workers in Scandinavia have been comparable to values in occupationally unexposed subjects in some regions in e.g. the US and UK with a higher environmental lead exposure from e.g. lead in drinking water, lead-based paint and emissions from lead industries (4). 
No significant correlations between the lead concentrations in any of the studied 7 bones and CBLI were evident in active lead workers. In this group, the daily intake from inhalational exposure from lead in air will have a stronger impact on lead in blood than the endogenous exposure from lead that is released from the skeletal pool. For retired lead workers, however, the inhalational exposure has ceased and accordingly the skeletal pool will more strongly influence the blood lead concentrations, often giving positive correlation coefficients (4-5). In this study, however, this pattern was not observed, probably partly dependent on the limited study population and a wide range of periods of retirement (3-20 years).

As earlier reported (20) and as also found in this study, strong positive correlations have been observed between lead concentrations in different types of cortical bones (Figure 1), especially for retired lead workers. Similarly, strong positive correlations were observed between lead levels in some trabecular bones (Figure 2). These findings indicate similarities in the metabolism for bones with the same basic structure.

Early XRF-measurements of lead exposed subjects were performed by Ahlgren et al (17-18). Thereafter, the technique has gradually been developed and used for studies of lead exposed workers $(5-6,8)$. The last three decades, in vivo measurements with XRF have been used to estimate the previous lead exposure in lead exposed populations (4-5, 8-10, 13, 21). The XRF-technique has also been used for lead determinations in occupationally unexposed subjects in Australia (7) and to evaluate the effect of chelation therapy on bone lead concentrations in lead exposed workers $(19,22-23)$.

\footnotetext{
As the highest bone lead concentrations were observed in finger bone in active and retired workers as well as in referents (c.f. Table 1), the XRF-technique can be
} 
used to determine the lead concentration in the second phalanx of the left index fingerbone (24). The combined data on bone lead concentrations and exposure time may be used to estimate a mean blood lead value during previous exposure periods. Such estimates can be valuable tools in epidemiological studies of adverse health effects in lead exposed subjects, for whom data on previous blood lead levels are lacking (24). 
Table 1. Mean values ( \pm SD) for age (y), exposure time (y), cumulative blood lead index $(\mathrm{CBLI} ; \mu \mathrm{mol} / \mathrm{L})$ and period of retirement $(\mathrm{y})$ in active and retired lead workers. Median values and ranges are given for lead concentrations in sternum, femur, finger-bone, vertebrae, iliac crest, rib and temporal-bone. The figures after the parentheses denote the number of bone lead samples which were analysed in each subgroup. All bone lead values in $\operatorname{ppm}(\mu \mathrm{g} / \mathrm{g}$ dry weight).

\begin{tabular}{|l|l|l|l|l|}
\hline Variables & $\begin{array}{l}\text { All workers } \\
\mathrm{N}=32\end{array}$ & $\begin{array}{l}\text { Retired workers } \\
\mathrm{N}=23\end{array}$ & $\begin{array}{l}\text { Active workers } \\
\mathrm{N}=9\end{array}$ & $\begin{array}{l}\text { Referents } \\
\mathrm{N}=10\end{array}$ \\
\hline Age & $67.4 \pm 9.5$ & $72.0 \pm 5.1$ & $55.7 \pm 7.8$ & $70.6 \pm 8.7$ \\
\hline Exposure time & $31.4 \pm 8.7$ & $32.0 \pm 9.0$ & $29.7 \pm 7.9$ & - \\
\hline CBLI & $66.4 \pm 23.8$ & $70.6 \pm 25.1$ & $55.7 \pm 16.9$ & - \\
\hline Period of ret & - & $9.0 \pm 4.2$ & - & - \\
\hline Sternum & $74(23-358) 31$ & $68(23-358) 22$ & $82(38-210) 9$ & $6(4-35) 10$ \\
\hline Femur & $56(15-155) 28$ & $68(15-155) 19$ & $50(21-99) 9$ & $13(7-22) 9$ \\
\hline Finger bone & $106(56-216) 18$ & $97(56-216) 13$ & $106(72-134) 5$ & $14(8-28) 8$ \\
\hline Vertebrae & $85(13-151) 17$ & $78(13-151) 12$ & $89(69-97) 5$ & $10(6-16) 8$ \\
\hline Iliac crest & $83(18-180) 18$ & $71(18-180) 13$ & $95(54-146) 5$ & $7(3-10) 8$ \\
\hline Rib & $70(34-211) 18$ & $66(34-172) 13$ & $75(35-211) 5$ & $8(2-19) 8$ \\
\hline Temporal bone & $59(23-203) 18$ & $61(33-151) 13$ & $45(23-203) 5$ & $15(10-26) 8$ \\
\hline
\end{tabular}


Table 2. Relationships (median quotients) between lead concentrations in finger bone (mainly cortical) and lead levels in sternum and vertebrae (mainly trabecular).

\begin{tabular}{|l|l|l|l|l|}
\hline Variables & $\begin{array}{l}\text { All workers } \\
\mathrm{N}=32\end{array}$ & $\begin{array}{l}\text { Retired } \\
\text { workers } \\
\mathrm{N}=23\end{array}$ & $\begin{array}{l}\text { Active } \\
\text { workers } \\
\mathrm{N}=9\end{array}$ & $\begin{array}{l}\text { Referents } \\
\mathrm{N}=10\end{array}$ \\
\hline Fingerbone/Sternum & 1.4 & 1.4 & 1.3 & 2.3 \\
\hline Fingerbone/Vertebrae & 1.2 & 1.2 & 1.2 & 1.4 \\
\hline
\end{tabular}




\section{REFERENCES}

1. Barry PSI. A comparison of concentrations of lead in human tissues. Br. J. Ind. Med. 1975; 32: 119-139.

2. Skerfving S. Biological monitoring of exposure to inorganic lead. In: Clarkson TW, Friberg L, Nordberg GF, Sager PR (eds). Biological monitoring of toxic metals. Rochester series on environmental toxicity. Plenum Press, New York 1988: pp 169-197.

3. Schütz A, Skerfving S, Christoffersson J-O, Ahlgren L, Mattsson S. Lead in vertebral bone biopsies from active and retired lead workers. Arch. Environ. Health 1987; 42: 340-346.

4. Gerhardsson L, Attewell R, Chettle DR, Englyst V, Lundström N-G, Nordberg GF, Nyhlin H, Scott MC, Todd AC. In vivo measurements of lead in bone in long-term exposed lead smelter workers. Arch. Environ. Health 1993; 48: 147156.

5. Christoffersson J-O, Schütz A, Ahlgren L, Haeger-Aronsen B, Mattsson S, Skerfving S. Lead in fingerbone analysed in vivo in active and retired lead workers. Am. J. Ind. Med. 1984; 6: 447-457.

6. Christoffersson J-O, Ahlgren L, Mattsson S, Schütz A, Skerfving S. Decrease of skeletal lead levels in man after end of occupational exposure. Arch. Environ. Health 1986; 41: 312-318.

7. Price J, Grudzinski AW, Craswell PW, Thomas BJ. Repeated bone lead levels in Queensland, Australia - previously a high-lead environment. Arch. Environ. Health 1992; 47: 256-262.

8. Nilsson U, Attewell R, Christoffersson J-O, Schütz A, Ahlgren L, Skerfving S, Mattsson S. Kinetics of lead in bone and blood after end of occupational exposure. Pharmacol. Toxicol. 1991; 68: 477-484. 
9. Börjesson J, Gerhardsson L, Mattsson S, Schütz A, Skerfving S. Österberg K. In vivo measurements of lead in fingerbone in active and retired lead smelters. Int. Arch. Occup. Environ. Health 1997; 69: 97-105.

10. Todd AC, Lee BK, Lee GS, Ahn KD, Moshier EL, Schwartz BS. Predictors of DMSA chelatable lead, tibial lead, and blood lead in 802 Korean lead workers. Occup. Environ. Med. 2001; 58: 73-80.

11. Silbergeld EK, Sauk J, Somerman M, Todd A, McNeill F, Fowler B, Fontaine A, van Buren J. Lead in bone: storage site, exposure source, and target organ. Neurotoxicology 1993; 14: 225-236.

12. Gerhardsson L, Brune D, Nordberg GF, Wester PO. Multielemental assay of tissues of deceased smelter workers and controls. Sci. Total. Environ. 1988; 74: 97-110.

13. Brito JA, McNeill FE, Stronach I, Webber CE, Wells S, Richard N, Chettle DR. Longitudinal changes in bone lead concentration: implications for modelling of human bone lead metabolism. J. Environ. Monit. 2001; 3: 343-351.

14. Brito JA, McNeill FE, Webber CE, Wells S, Richard N, Carvalho ML, Chettle DR. Evaluation of a novel structural model to describe the endogenous release of lead from bone. J. Environ. Monit. 2002; 4: 194-201.

15. Tsaih SW, Korrick S, Schwartz J, Lee ML, Amarasiriwardena C, Aro A, Sparrow D, Hu H. Influence of bone resorption on the mobilization of lead from bone among middle-aged and elderly men: the normative aging study. Environ. Health Perspect. 2001; 109: 995-999.

16. Elmarsafawy SF, Tsaih S-W, Korrick S, Dickey JH, Sparrow D, Aro A, Hu H. Occupational determinants of bone and blood lead levels in middle aged and elderly men from the general community: the normative aging study. Am. J. Ind. Med. 2002; 42: 38-49. 
17. Ahlgren L, Lidén K, Mattsson S, Tejning S. X-ray fluorescence analysis of lead in human skeleton in vivo. Scand. J. Work. Environ. Health 1976; 2: 82-86.

18. Ahlgren L, Haeger-Aronsen B, Mattsson S, Schütz A. In-vivo determination of lead in the skeleton after occupational exposure to lead. Br. J. Ind. Med. 1980; 37: 109-113.

19. Tell I, Somervaille LJ, Nilsson U, Bensryd I, Schütz A, Chettle DR, Scott MC, Skerfving S. Chelated lead and bone lead. Scand. J. Work Environ. Health 1992; 8: 113-119.

20. Somervaille LJ, Nilsson U, Chettle DR, Tell I, Scott MC, Schütz A, Mattsson S, Skerfving S. In vivo measurements of bone lead - a comparison of two X-ray fluorescence techniques used at three different bone sites. Phys. Med. Biol. 1989; 34: 1833-1845.

21. Ahlgren L, Mattsson S. An X-ray fluorescence technique for in vivo determination of lead concentrations in a bone matrix. Phys. Med. Biol. 1979; 24: $136-145$.

22. Sokas RK, Besarab A, McDiarmid MA, Shapiro IM, Bloch P. Sensitivity of invivo X-ray fluorescence determination of skeletal lead stores. Arch. Environ. Health 1990; 45: 268-272.

23. Gerhardsson L, Börjesson J, Mattsson S, Schütz A, Skerfving S. Chelated lead in relation to lead in bone and ALAD genotype. Environ. Res. 1999; 80: 389398.

24. Börjesson J, Strömberg U, Mattsson S, Gerhardsson L, Schütz A, Skerfving S. Lead in fingerbone: a tool for retrospective exposure assessment. Arch Environ Health 1997; 52: 104-112. 


\section{FIGURE LEGENDS}

Figure 1. 3-D plot of lead concentrations ( $\mu \mathrm{g} / \mathrm{g}$ dry weight) in femur and finger bone vs cumulative blood lead index (CBLI; $\mu \mathrm{mol} / \mathrm{L})$ in lead workers.

Figure 2. 3-D plot of lead concentrations ( $\mu \mathrm{g} / \mathrm{g}$ dry weight) in sternum and vertebrae vs cumulative blood lead index (CBLI; $\mu \mathrm{mol} / \mathrm{L})$ in lead workers. 